\title{
A STUDY ON SOCIO- ECONOMIC CONDITIONS AND PROBLEMS OF STREET VENDORS IN COIMBATORE CITY
}

KEY WORDS: Street Vendors, Socio-economic Conditions, Problems.

\section{Dr. G Jayanthi}

\section{Baranipriya $A *$}

\section{Sreeanandan}

Assistant Professor, Department Of Economics, PSG College Of Arts \& Science, Coimbatore

PhD Research Scholar, Department Of Economics, PSG College Of Arts \& Science, Coimbatore *Corresponding Author

PhD Research Scholar, Department Of Economics, PSG College Of Arts \& Science, Coimbatore

Street vending is a global phenomenon and the most visible aspect. Like other informal sector, street vending is characterized by low level of income, easy of entry, self employed and it involves large number of people. The study examines socio economic condition and problems faced by the street vendors in Coimbatore city. This study has been used Percentage and Garrett Ranking Technique. The result reveals that, female's contribution in this sector is lesser than the male respondents and they were facing problems like health issues, wastage of unsold goods, and insecurity in employment. Therefore, the government should take some corrective measures to improve their socio- economic and living conditions of street vendors.

\section{INTRODUCTION}

Street vendors are the most visible section of the informal economy. Street and Road side vending is an economic activity and it consists of a large percentage of rural and urban dwellers in developing countries. There has been continuous growth of road side vendors not only in India but also in the entire world. Vendors are defined from an economic, cultural and legal position, are those people who offer goods or services for sale from public places, primarily streets and pavements. These roadside vendors are characterized by low income group. Street vendors are very sizable proportion of the informal sector in the India. It projected the 2 to 2.5 percent of the total population in several cities in India. In terms of total numbers, there are an estimated ten million or more street vendors are existed in India (MHUPA 2009). Street vending is one of the important income and employment source and it provide good and service to poor at affordable price and convenient to urban poor population in town and cities.

\section{OBJECTIVE OFTHE STUDY}

- To understand socio- economic conditions of street vendors in Coimbatore city

- To identify the problems faced by street vendors in Coimbatore city

\section{STATEMENT OF THE PROBLEM}

In developing countries like India, the informal sectors including street vending take up the majority of the urban unemployed growing labor force. It creates a wide employment opportunity; it is a means for income generation for the marginalized groups, and the urban poor people. How ever, despite its increasing importance in the total economy, policies, regulations, services, infrastructure facilities and institutional support programme are not available for the street vending and the environment under which the vendor operate their business are not suitable for their health and wellbeing. In addition, street vendors face many problems in the course of running their activities. It is therefore, the focus of this study is to access the Socio-economic conditions and problems faced by the street vendors in Coimbatore city.

\section{METHODOLOGY}

The study was based on primary data collected from street vendors by direct interview method. An interview schedule had been prepared to analyze socio economic status inclusive problems of street vendors in Coimbatore city. In Coimbatore city 18,231 street vendors have registered and have obtained license under the Food Safety and Standards Act, 2006 in the year 2018. Based on the time and costs constraints the researcher collected the data only from 75 street vendors using Simple Random Sampling. For the analysis purpose Percentage and Garrett Ranking Technique were used.

\section{FINDINGS AND ANALYSIS}

The classification of the respondents according to their socioeconomic status is given in the following table.

Table 1 Socio Economic conditions of street vendors

\begin{tabular}{|c|c|c|c|c|}
\hline S. No & Variables & Particulars & $\begin{array}{c}\text { No. of } \\
\text { respondents }\end{array}$ & Percentage \\
\hline \multirow[t]{3}{*}{1} & \multirow[t]{3}{*}{ Age } & Below 20-40 & 37 & 49 \\
\hline & & $40-60$ & 34 & 45 \\
\hline & & Above 60 & 4 & 6 \\
\hline \multicolumn{3}{|c|}{ Total } & 75 & 100 \\
\hline \multirow[t]{2}{*}{2} & \multirow[t]{2}{*}{ Gender } & Male & 54 & 72 \\
\hline & & Female & 21 & 28 \\
\hline \multicolumn{3}{|c|}{ Total } & 75 & 100 \\
\hline \multirow[t]{3}{*}{3} & \multirow{3}{*}{$\begin{array}{l}\text { Marital } \\
\text { Status }\end{array}$} & Married & 57 & 76 \\
\hline & & Unmarried & 17 & 23 \\
\hline & & Widow & 1 & 1 \\
\hline \multicolumn{3}{|c|}{ Total } & & 100 \\
\hline \multirow[t]{5}{*}{4} & \multirow{5}{*}{$\begin{array}{l}\text { Educational } \\
\text { Qualification }\end{array}$} & Illiterate & 18 & 24 \\
\hline & & Primary & 20 & 27 \\
\hline & & Secondary & 25 & 33 \\
\hline & & \begin{tabular}{|l|} 
Higher \\
secondary
\end{tabular} & 6 & 8 \\
\hline & & $\begin{array}{l}\text { Degree \& } \\
\text { above }\end{array}$ & 6 & 8 \\
\hline \multicolumn{3}{|c|}{ Total } & 75 & 100 \\
\hline
\end{tabular}

\section{Source: Field Survey}

The study has classified into four age groups i.e. $20-40$ years, 40-60 years and Above 60 years. Most of the respondents belongs to the age group of $20-40$ years ( $49 \%$ ), followed by 40-60 years $(45 \%)$, and remaining 6 percent of the respo ndents belongs to above 60 years. Most of the respondents were male vendors i.e. $54(72 \%)$, and the female vendors were $21(28 \%)$. It reveals that female's contribution in this sector is lesser than the male respondents. The study revealed that, most of the respondents were married (76\%) followed by 
unmarried (23\%) and widow (1). The study has found the workers belong to different levels of educational qualifi cation. The study shows that majority of the respondents have completed their secondary level (33\%). Primary level completed by $20(27 \%)$ respondents. About 24 per cent of respondents were illiterate and least percentage $(8 \%)$ of the respondents completed their higher secondary and graduation.

Table 2 Problems faced by the street vendors

\begin{tabular}{|l|c|c|}
\hline \multicolumn{1}{|c|}{ Problems } & Garrett Score & Rank \\
\hline Health problem & 4956 & 1 \\
\hline Heavy competition & 4082 & 4 \\
\hline Online shopping & 4052 & 5 \\
\hline Wastage of unsold goods & 4133 & 2 \\
\hline Feeling insecurity & 4120 & 3 \\
\hline $\begin{array}{l}\text { Fear of customers misbehaving and } \\
\text { bargaining }\end{array}$ & 3637 & 6 \\
\hline $\begin{array}{l}\text { Fear of municipal and higher } \\
\text { authorities }\end{array}$ & 3575 & 8 \\
\hline $\begin{array}{l}\text { Environmental hazards } \\
\text { Inadequate shelter, drinking water, } \\
\text { sanitation }\end{array}$ & 3608 & 7 \\
\hline Difficult to get vending license & 2401 & 9 \\
\hline
\end{tabular}

\section{Source: Field Survey}

From the table, most of the respondents facing health issues and it was the major problem of the respondents. And this problem was considered as first rank followed by wastage of unsold goods and feeling insecurity ranked as second and third problems. Heavy competition ranked as fourth in the survey. Today majority of the respondents prefers online shopping hence the number of the street vendors were reduced, so it was ranked as fifth. Fear of customers misbeh aving and bargaining the prices of goods was ranked as sixth. Few of the respondents facing Environmental hazards like pollution \& natural disasters, hence it was ranked as seventh. Then fear of municipal and higher authorities ranked as eighth because the restriction imposed by the government is very strict. Inadequate shelter, drinking water and sanitation ranked as ninth. And difficult to get vending license procedures was ranked as tenth.

\section{CONCLUSION}

Street sending is an important source of self employment to the poor in cities and towns but also a means to provide affordable as well as convenient service to a majority of the urban population. The poorer sections are able to procure their basic necessities mainly through street vendors as the goods sold are cheap. The study revealed that street vendors considered as most vulnerable group in the unorganized sector at the same time their income levels are very low and uncertain. Though, they were facing some of the major problems like health issues, insecurity in employment, wastage of unsold goods and heavy competition.

\section{REFERENCES}

1. Bhowmik (2001), "Education Level of Street Vendors and its Impact on Performance of the activity: A case study of Hyderabad, Telangana", International Journal of Research in Economics and Social Science, 7 (7), pp. 436-443

2. Kanth, Amod K. (2000),"Vendors, Police \& Governance", in Seminar, No. 491 , July, pp.32-35

3. Karthikeyan, R. and Mangaleswaran, R. (2013), "Quality of life among street vendors in Tiruchirappalli City, Tamilnadu, India",International Research Journal of Social Sciences, 02(12), pp. 18-28

4. Mavalankar D and A.K. Srivastava, (2008), "Lessons from Massive Floods of 2006 in Surat City: A framework for Application of MS/OR Techniques to Improve Dam Management to Prevent Flood", IIM,Ahmedabad

5. MHUPA (2011) "Model Street Vendors (Protection of Livelihood and Regulation of StreetVending) Bill-2009." 